\title{
A roupa nova do presidente: a politização da imagem pública de Jânio Quadros (1947-1961)
}

\begin{abstract}
Jefferson J. Queler ${ }^{1}$
RESUMO: A imagem pública de Jânio Quadros é frequentemente considerada como desprovida de quaisquer significados políticos, seja por historiadores ou pela memória coletiva. Na maioria dos casos, ele é tratado como um demagogo que se promovia apenas através de seu personalismo, exibindo-se em suas aparições públicas despenteado e com camisas abertas no colarinho. Tal perspectiva está profundamente relacionada com a forma pela qual seus oponentes e inimigos o representavam nos debates políticos, e em seu cerne foi bem-sucedida, tendo penetrado na historiografia. Neste texto, porém, pretendo sugerir que, perpassando a década de 1950 e o início da de 1960, desde o início de sua carreira até o momento em que disputou eleições presidenciais e foi o presidente do Brasil, as imagens de Jânio veiculavam um amplo leque de sentidos políticos. Por meio de gestos e roupas, destacando-se aí seus slacks indianos, ele procurou expressar seus projetos relacionados à Democracia Cristã e à Política Externa Independente. Para lidar com essa hipótese, as principais fontes fotográficas e textuais elencadas são as revistas $\bigcirc$ Cruzeiro e Manchete da época, e outras fotos e ilustrações que então foram bastante difundidas.

PALAVRAS-CHAVE: Democracia cristã. Imagem. Jânio Quadros. Política. Política externa independente. Slacks.

ABSTRACT: Jânio Quadros public image is often considered deprived of any political meaning either by historians or by collective memory. In most cases he is treated as a demagogue who promoted himself only through his personalism, which could be seen in his public appearances unkempt and with open-necked shirts. Such perspective is deeply related to the way his opponents and enemies represented him in the political debates, and its core has been successful in penetrating the historiography. However in this text I intend to suggest that Jânio's images conveyed an array of political senses during the 1950s and early 1960s, since the beginning of his career till when he disputed presidential elections and ruled Brazil as president. Through his gestures and clothes, among which his Indian slacks deserve more attention, he tried to express his project related to the Christian Democracy and the Independent Foreign
\end{abstract}

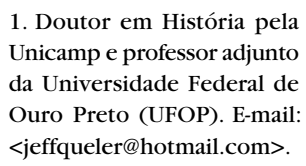

$<$ jeffqueler@hotmail.com>. 
2. Cf. Almirante Carlos P. Botto (1961, p. 85). A grafia, neste e em todos os textos da época, foi atualizada.

3. Este artigo é parte de minha tese de doutorado em História, financiada pela $\mathrm{Fa}$ pesp e orientada pela profa. Dra. Vavy Pacheco Borges na Unicamp; ver Jefferson J. Queler (2008). Quero aqui agradecer a Silvana Louzada da Silva bem como aos pareceristas anônimos destes Anais.

4. É muito vasta a bibliografia com essa perspectiva. De qualquer forma, dois exemplos muito importantes podem ser encontrados em Francisco Weffort (1978) e Vera Chaia (1991). Sobre as críticas à noção de populismo, a coletânea organizada por Jorge Ferreira é fundamental; ver Jorge Ferreira (2001).

5. Tenho em mente proposições do tipo: "É pelos olhos que se prendem os homens, pois assim se adormece mais facilmente sua desconfiança"; cf. Pierre Francastel (1993, p. 29).
Policy. To deal with such hypothesis, the main sources will be the magazines $\bigcirc$ Cruzeiro and Manchete and others photos and drawings that were considerably widespread at that time. KEY-WORDS: Christian democracy. Image. Independent foreign policy. Jânio Quadros. Politics. Slacks.

"Lembrando conhecido conto de Andersen, o Presidente está quase
desnudo, apenas envolto em transparentes tecidos socializantes,
mas o Chanceler insiste em apresentá-lo vestido com felpuda roupa-
gem democrática modelo ltamarati dos áureos tempos de Rio Bran-
co e Joaquim Nabuco. Mas aqui, não é só o garoto a gritar: 'o Rei
está nu'; é toda a população esclarecida do Brasil a constatar o
fato, apesar de tropos oratórios e devaneios acadêmicos."2 Almirante Carlos Penna Botto, 1961

Esta alusão a Jânio Quadros, da parte do então líder da Cruzada Brasileira Anticomunista, apareceu num momento em que o primeiro conduzia o projeto da chamada Política Externa Independente, voltado, entre outras coisas, para o restabelecimento de relações comerciais entre o Brasil e países do Leste Europeu sob regimes de inspiração comunista. Na época, curiosamente, em seus despachos diários e cerimônias oficiais, o presidente deixava-se fotografar trajando slacks, de uso comum em certas regiões do Oriente mas logo ridicularizados por aqui; segundo o epíteto em voga em círculos políiticos e da imprensa, constituíam tão-somente o "piiânio". Haveria alguma associação entre esses acontecimentos? Estaria sua imagem pública politizada a ponto de seus adversários e inimigos tentarem dissociá-la de eventuais programas partidários? $?^{3}$

Em caso afirmativo, seria possível estabelecer contrapontos a interpretações que tratam a ascensão políitca de Jânio Quadros como resultado principalmente de seu personalismo, ao elencá-lo como exemplo de líder "populista" ${ }^{4}$. Da mesma forma, seria ocasião interessante para problematizar assertivas que apontam a iconografia como elemento altamente despolitizador, como artifício para driblar mais facilmente o senso crítico dos indivíduos ${ }^{5}$. Ao que parece, desde que ele iniciou sua carreira política em 1947 até sua renúncia à Presidência em 1961, fotografias e outras imagens relacionadas a Jânio participaram explicitamente do debate público. Com a abordagem aqui feita, não pretendo desvelar a verdadeira faceta do líder naquelas circunstâncias, mas sugerir como, em meio a numerosos confrontos entre imagens, seus opositores intentaram negar-he quaisquer sentidos políticos, algo que parece ter sido bem-sucedido em cristalizar-se na memória coletiva e na historiografia. Para desenvolver as referidas hipóteses, são utilizadas, principalmente, as revistas $\bigcirc$ Cruzeiro e Manchete, ambas de grande circulação nacional no período.

Chaplin também faz política

Após ter concluído seus estudos secundários no colégio Arquidiocesano e feito sua formação superior na tradicional faculdade de Direito do largo de São 
Francisco, ambos em São Paulo, Jânio da Silva Quadros passou a atuar num pequeno escritório de advocacia e a lecionar em colégios como o Dante Alighieri e o Vera Cruz. Em 1946, após a redemocratização do país, candidatou-se, na cidade de São Paulo, a uma vaga de vereador pelo Partido Democrata Cristão (PDC). Felipe Santos Magalhães indicou como muitos trabalhos que lidaram com o tema apontaram que o político conseguiu apenas uma vaga de suplente naquela disputa, tendo assumido o cargo supostamente por conta da cassação dos mandatos de vereadores do Partido Comunista do Brasil (PCB), em 1947. Contudo, Magalhães demonstrou que, nessa eleição, o PDC obteve três cadeiras para a vereança paulistana, com o detalhe de que Jânio obteve a segunda maior votação. Desse modo, sua cadeira já estava garantida após a apuração dos votos, e ele logo em seguida foi diplomado pelo Tribunal Regional Eleitoral (TRE) de São Paulob. Daí em diante, foi eleito deputado estadual, prefeito de São Paulo, governador de São Paulo, deputado federal e, finalmente, em 1960, presidente da República.

Tantos anos da existência de um homem, tratados assim de forma tão ligeira, com certeza não são suficientes para explicar sua projeção no cenário político brasileiro. Nos primeiros anos de sua vida, provavelmente foram criados laços entre Jânio e os grupos sociais que o apoiaram no pleito municipal de 1946. É o que sinaliza a biografia feita pelo jornalista José Yamashiro, encomendada e publicada pela Livraria Lima, de Porto Alegre, logo após sua vitória nas eleições presidenciais de 1960. Na fala de Nilo Gordo de Vergueiro, colega de Jânio na época do colégio entrevistado pelo autor, surgem pistas interessantes:

A turma de 1933 do Colégio Arquidiocesano era, como ainda é, muito unida e amiga [...] esse grupo foi responsável pela fundação da Associação dos Antigos Alunos Maristas do Colégio, cujos membros "unem-se em torno de qualquer colega que precise de seu auxílio ou apoio". Quando JQ foi candidato à vereança, seus antigos colegas de colégio vieram prestar-the auxilio na divulgação de seu nome e de material de propaganda?

Ao que parece, sua ascensão à vereança de São Paulo não se deu apenas com lances histriônicos, como quiseram muitos de seus adversários ou mesmo grande parte da historiografia. Parecia haver também certo respaldo social. Aponta igualmente para essa direção o trabalho de Silvana Walmsley ${ }^{8}$. Na opinião da autora, são problemáticas as interpretações que (especialmente nas eleições para prefeito em 1953) explicam a força política de Jânio a partir de elementos como demagogia e manipulação, pois sua vitória naquelas circunstâncias coincidiu com a "greve dos 300 mil" em São Paulo, tida por considerável parte da historiografia como uma "autêntica" manifestação dos trabalhadores. Para aprofundar essa questão, a autora acompanhou a evolução das condições de vida e de trabalho dos operários na conjuntura das eleições municipais. Demonstrou, então, que a inflação se intensificou, os salários foram corroídos, os gêneros de primeira necessidade tiveram sua distribuição obstaculizada, e um aumento na exploração do trabalho tornou-se patente. Nesse quadro, as inquietações e motins ocorridos entre os trabalhadores não foram explicados por ela simplesmente como questões de "pão e manteiga": não se mobilizavam apenas por
6. Cf. Felipe S. Magalhães (1998, p. 91).

7. Nilo Gordo de Vergueiro, apud José Yamashiro (1961, p. 38-39).

8.Ver Silvana.M.de M.Walmsley (1992, passim) 
9. Maria Victória M. Benevides destaca que, em 1953 e 1954, a atuação política de Jânio despertava o entusiasmo de socialistas e até mesmo de trabalhistas mais identificados com a "esquerda". E fornece exemplos da atuação dele na Assembleia Legislativa estadual: "Jânio é sempre o mais freqüente crítico da 'plutocracia danosa' (como J. J.Abdalla) e da 'volúpia dos ricos', denunciando os 'salários humilhantes dos trabalhadores'. É igualmente o primeiro a denunciar aumentos extorsivos nas contas de água e de luz e nos transportes públicos, assim como defende o direito dos ambulantes e dos favelados contra remoção pelos poderes públicos [...] ainda defende os migrantes nordestinos, os motoristas de táxi (e seu direito a ponto livre), os líderes sindicais, os professores e os aposentados; denuncia os latifundiários, a corrupção e a violência na polícia e o péssimo atendimento nos serviços de saúde; finalmente, é o nacionalista que repele os monopólios, os trustes e os cartéis. Ao lado dessa atuação constante em favor dos 'pobres e humildes', o deputado democrata-cristão inicia sua radical campanha contra qualquer vislumbre de corrupção no poder público". Cf. Maria Victória M. Benevides (1987, p. 58-59).

10. Em 1954, disputou o governo do estado de São Paulo pelo Partido Trabalhista Nacional (PTN). Em 1958, candidatou-se a deputado federal pelo PartidoTrabalhista Brasileiro (PTB). Enfim, em 1959, retornou ao PTN para concorrer nas eleições presidenciais.

11. Cf. J. Pereira (1959, p. 146-147).

12.Algumas informações sobre ambas as revistas podem ser encontradas nos verbetes com os respectivos nomes em Alzira A. de Abreu et al. (2001). sentir fome, mas também por ter percebido que autoridades e atravessadores rompiam limites moralmente aceitos na gestão de recursos e víveres.

E é muito significativo que os discursos de Jânio, desde a vereança até a candidatura para prefeito, estivessem repletos de críticas a essa situação, bem como de propostas para a melhora das condições de vida dos trabalhadores?. Dessa forma, o catolicismo social presente em suas falas, inspirado nas encíclicas Rerum Novarum e Quadragesimo Anno, com seus princípios de valorização do homem em meio à intensificação da exploração do trabalho, parece ter surgido como alternativa concreta a seus seguidores. E esse projeto políitico o acompanhou ao longo de sua carreira política, mesmo ele tendo abandonado o PDC e trocado muitas vezes de partido ${ }^{10}$. Em 1955, por exemplo, ao discursar como governador, reafirmou seus compromissos com a democracia cristã em meio a críticas, por um lado, à "alta do custo de vida, que tantas amarguras tem causado aos proletários"; e, por outro, ao "luxo escandaloso" e a "cupidez humana"; também conclamou seus ouvintes a construírem um Brasil diferente: "Mais cristão. Mais justo. Generoso para os humildes e pequenos. Propiciador de iguais oportunidades para todos"11.

Durante a campanha presidencial que disputou, foi através de revistas ilustradas de variedades, como $O$ Cruzeiro e Manchete, que, em âmbito nacional, Jânio veiculou muitas de suas propostas; ou recebeu críticas. A primeira, atuante desde a década de 1920, fazia parte da cadeia de veículos de comunicação dos Diários Associados, encabeçada pelo empresário e político Assis Chateaubriand. Veículo de maior circulação do gênero no Brasil da década de 1950, o periódico oscilou entre o apoio à candidatura presidencial de Vargas e a oposição às medidas do governo deste último em relação à defesa do monopólio estatal do petróleo. Em seguida, apoiou as candidaturas de Juscelino Kubitschek e do Marechal Lott à Presidência. Sua tiragem semanal, ao longo daqueles anos, ficou em 550 mil exemplares em média.

A segunda, por sua vez, fundada em 1952 e presidida por Adolfo Bloch, constituiu-se como a grande concorrente de $O$ Cruzeiro. Entre seus posicionamentos políticos, sobressaía seu apoio ao governo Kubitschek e ao chamado desenvolvimentismo. Quanto aos dados sobre sua circulação, consta que vendeu 760 mil exemplares com sua edição referente à inauguração de Brasília, o que indica que vendia bem menos em ocasiões menos notórias ${ }^{12}$.

Em sua disputa pela Presidência, Jânio era acusado de se ter projetado na política nacional meramente com lances teatrais, o que ele e seus simpatizantes evidentemente negavam. A Figura 1 fornece pistas desse debate. Trata-se de um retrato seu na Câmara Municipal de São Paulo, publicado na revista $O$ Cruzeiro logo após sua vitória nas eleições presidenciais. Essa fotografia encerra problemas para nossa análise: não sabemos quem é seu autor nem se ela já circulara na imprensa, o que limita a análise das intenções políiticas do fotógrafo ou de um possível trabalho de edição anterior. Nela, de qualquer forma, Jânio aparece com a barba crescida, o cabelo revolto e as roupas desalinhadas, captado com expressão de espanto e gesticulação vivaz. Na legenda, há a indicação de que essa foło foi divulgada com o intuito de apontar uma mudança em sua postura pública, tratada como mais alinhada e contida na Presidência da República; portanto, um uso da fotografia com sentido 


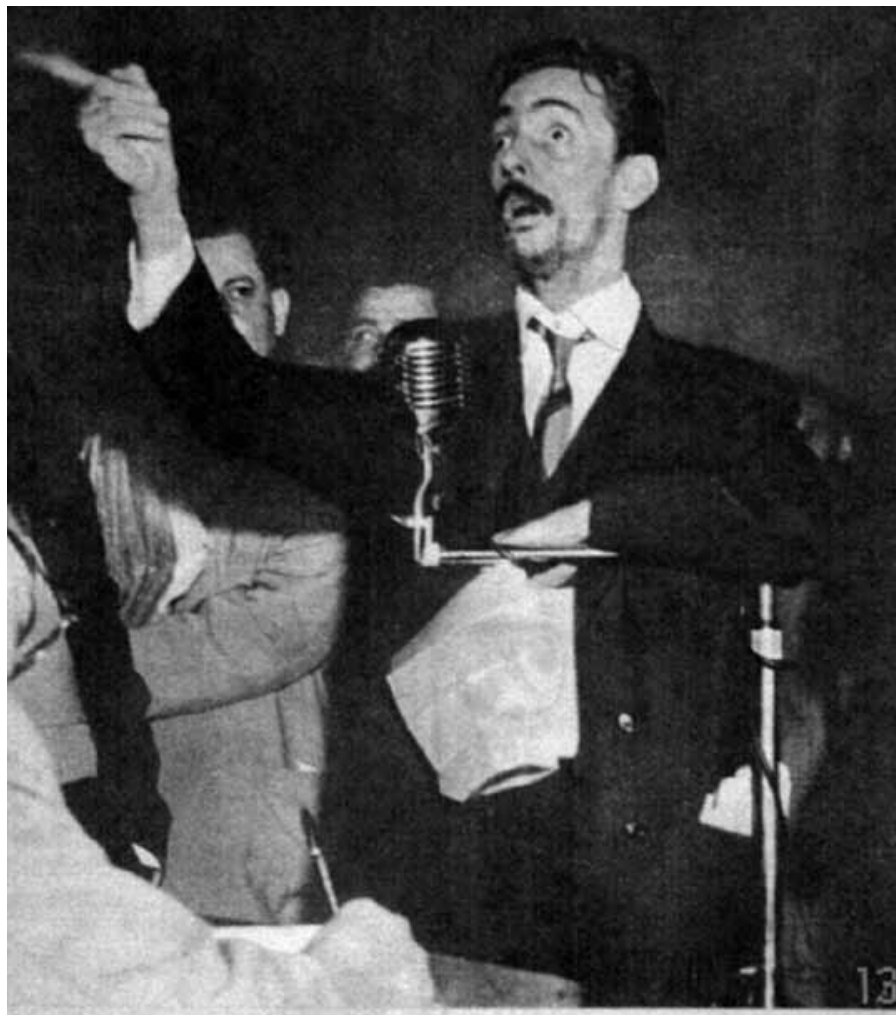

M gesticulaçăo vivo, polavro inflamodo, roupa em desolinho, eis o Jänio Quodros vereodo 1949 , em S6o Poulo. Agoro estó diterente: aporou a borbo e endireitou a gravato
Figura $1-\bigcirc$ antigo bufão. Fonte: 0 Cruzeiro 129 out. 1960, p. 7). positivo. Essa caracterização de personagem grotesco e efusivo vai acompanhá-lo durante toda a sua carreira política, ora exaltando-o, ora desqualificando-o.

Poderíamos nos perguntar, na época, sobre os significados de representações como essa, fosse para Jânio ou para seus seguidores. A simbologia de seus ímpetos e manifestações de emoções é evidenciada em entrevista coletiva por ele concedida quando estava à frente do governo do estado de São Paulo. Ao responder por que era tão ríspido na administração, atendendo à solicitação de um repórter, disse que seu governo não fazia distinções entre "um poderoso ou um humilde" por adotar "um só peso e uma só medida". Admitindo que às vezes cometia injustiças, justificou-se: "Mas é um governo que não poderia escapar dos excessos. Porque representa e incorpora a cólera popular. E a cólera popular sempre aparece com traços de violência [...] E a tornam por isso mesmo a correção, última e invencível dos abusos de qualquer natureza"13. Algo semelhante é expresso em trecho de discurso que fez ao inaugurar um comitê em prol de sua candidatura em São Paulo, em 28 de dezembro de 1959. Antes de mais nada, ele aponta problemas no país, como o desrespeito às leis, a desorganização da produção, a corrupção em órgãos públicos e o aumento da inflação. E tudo isso coexistiria com tramas e atitudes de indiferença na administração pública. Finalmente, lança uma advertência a "esses políticos cavilosos": "cuidado com o povo, porque quando ele se zanga e sua paciência se esgota, extravasa-the a cólera. Ai daqueles, então, que incorrem na ira popular"14. Mostras de furor que
13.Jânio da S. Quadros, apud J. Pereira (1959, p. 45).

14. Cf.Vidal dos Santos \& Luiz Monteiro ([196?], p. 129) 
15. Cf. Viriato de Castro (1959, p. 70-71).

16. Cf. Georges Balandier (1992, p. 53).

17. Henrique Teixeira Lott, apud Vidal dos Santos \& Luiz Monteiro ([196?], p. 43.)

18. Abelardo Jurema (23 out. 1959). Disponível em $<$ www.camara.gov.br>. tinham, portanto, como um de seus objetivos, a mobilização de paixões coletivas para a concretização de mudanças por meio da políitica.

Ademais, tais irrupções de fúria eram expressas por meio de um conhecido personagem da cultura popular: o bufão. Ele pode ser entrevisto em biografia sobre Jânio escrita por um de seus simpatizantes em meados da década de 1950 e que, para ser publicada, foi revista no momento das eleições presidenciais. Para Viriato de Castro, o surgimento daquela figura excêntrica na políitca brasileira é uma espécie de divisor de águas: "Jânio era um homem pobre, humilde, simples, saído do nada, vestindo-se desleixadamente, cabelos revoltos, trazendo no rosto todos os sofrimentos e desenganos de todos os jânios [...] que existiam nos bairros populosos da Capital paulista"; em contraposição a políiticos "bem parecidos, bem vestidos, bem postos, cuja linguagem além de transparecer falta de sinceridade, era muitas vezes mesmo cínica, engraçada, anedótica"15. O personagem imaginário do bufão aflora: alguém que mostra serem passíveis de desconstrução as distinções e classificações impostas pela cultura e pela sociedade, com o propósito de reconstruíla; que cria na desordem, com a apresentação de um comportamento maluco, fora das convenções sociais; que rompe as censuras mais constrangedoras, até mesmo com ímpetos de obscenidade e violência ${ }^{16}$.

Evidentemente, os opositores de Jânio procuraram esvaziar esses sentidos no jogo político. Tratavam-no, em geral, como alguém que "perde com extrema facilidade o controle emocional quando enfrenta uma situação que não the é cômoda", conforme declarou o Marechal Lott, seu principal oponente nas eleições presidenciais, num momento em que o primeiro o criticava por admitir abandonar a disputa em favor de um nome de "união nacional"17. Ainda sobre esse episódio, em 23 de outubro de 1959, o deputado Abelardo Jurema, do Partido Social Democrático (PSD), afirmou na Câmara que Jânio "exaltou a vida política brasileira, louvou o Senhor Juscelino Kubitschek e seu governo, elogiou a obra de Brasilia"; reconhecimento das instituições e das práticas políiticas no país que, de repente, teria sido deixado de lado com o referido pronunciamento do Marechal Lott: "Tudo isso foi esquecido no instante em que eclodiram dentro de si as paixões, no instante em que não pôde controlar sua emotividade"18.

As Figuras 2 e 3 talvez nos ajudem a compreender mais claramente essas posições. Elas se referem, respectivamente, a um retrato do Marechal Lott e a uma série de fotos de Jânio em convenção da União Democrática Nacional (UDN), quando sua candidatura foi apoiada por esse partido. Ambos foram publicados lado a lado na Manchete, em 2 de janeiro de 1960, com uma página para cada. Na apresentação, os candidatos são identificados como personalidades políticas de destaque no país. Lott surge sentado e de uniforme militar, tendo em frente de si uma mesa e, no fundo, um mapa do Brasil. Fixado com olhar oblíquo em relação à câmera, expressão séria, aponta para frente com uma das mãos. Jânio, por sua vez, figura em quatro posições que, tomadas em conjunto, enfatizam a movimentação de sua cabeça, suas mãos e seu semblante rumo a várias direções.

Essas imagens são complementadas por dois pequenos textos que tratam do que seriam as personalidades de cada um (títulos: Henrique Lott, o bravo; Jânio Quadros, o mais discutido). Neles, lê-se uma curta biografia do primeiro, desde suas 


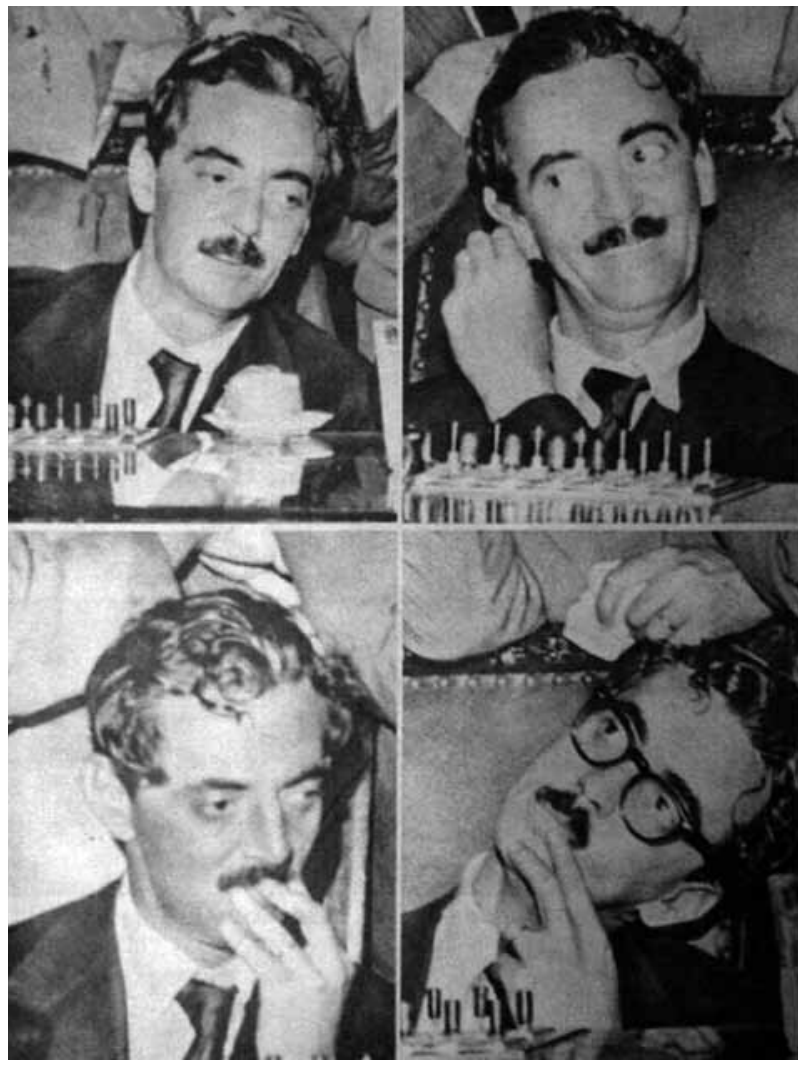

Figuras 2 e 3 - $\bigcirc$ condutor e a nau desgovernada. Fonte: Manchete (2 jan. 1960, p. 56, 57).

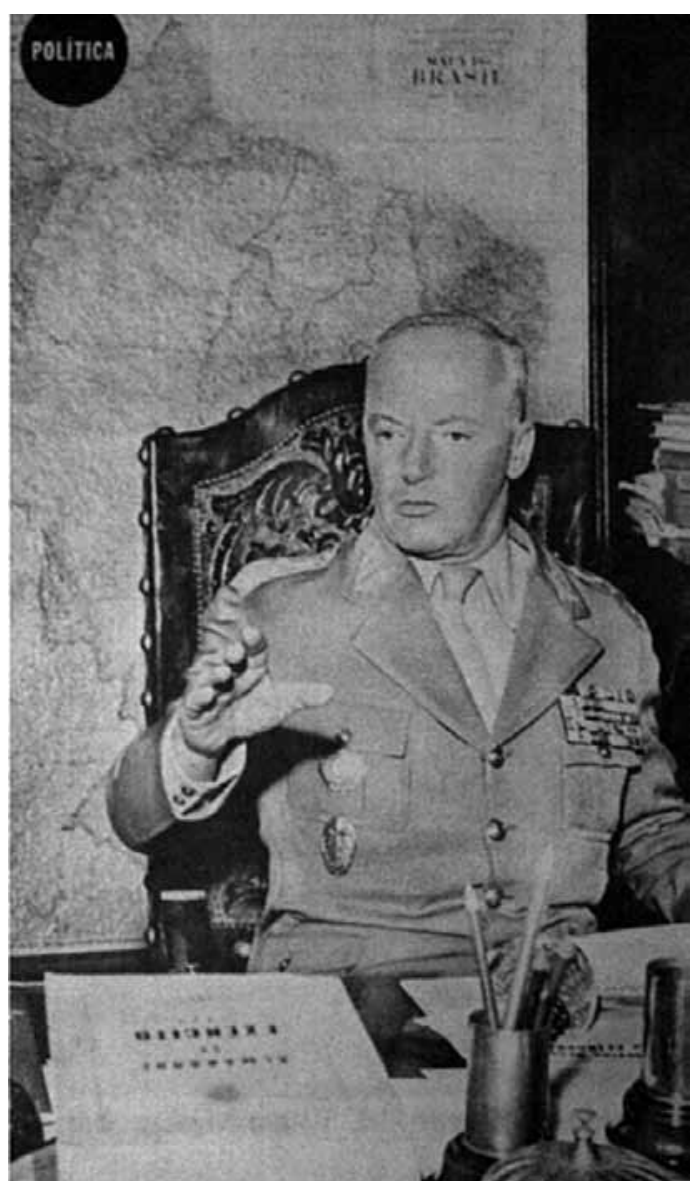

Annals of Museu Paulista. v. 19. n.1. July.-Dec. 2011. 
19. Cf. Claudine Haroche (1998, p. 36).

20. Cf. J. Pereira, 1959, p. 1112.

21. Ver Jorge Ferreira (1959).

22. Idem, ibidem. atividades no Exército até sua entrada no cenário político nacional, bem como um resumo das supostas tergiversações do último antes de assumir sua candidatura: "Os quatro flagrantes retratam suas emoç̃oes ao ser indicado seu nome na convenção da UDN". Dessa forma, o coniunto formado pelo trabalho de edição da revista procura representar as personalidades de cada um dos candidatos uma em contraposição à outra, ao mesmo tempo em que sugere a influência dessas supostas características num eventual governo. Ao passo que o Marechal Lott aparece como um líder firme e decidido, Jânio surge como um homem inconstante e governado pelas emoções, isto é, sem uma direção definida para imprimir ao Brasil. É preciso lembrar que o controle de si é um velho tema do pensamento político e das práticas dos governantes. Nos comentários de Claudine Haroche sobre a habitual contenção da gestualidade monárquica, por exemplo, temos que: "A mobilidade descontrolada, a excitação, o rebuliço aparecem [...] como signos de uma despossessão, de uma posição de inferioridade, ao passo que o domínio de si representa a posição de uma superioridade, um elemento central de dominação"19. Questões semelhantes pareciam estar no centro dos debates políticos durante as referidas eleições presidenciais no Brasil.

Não deve ser casual, pois, que Jânio se apresentasse como um administrador racional e eficiente. Como alguém que, uma vez eleito, varreria os desvios de verbas e as práticas de apadrinhamento na administração pública; daí o seu famoso símbolo da vassoura. Não deve ser por menos que, no governo de São Paulo, passou a escrever seus memorandos à mão, jocosamente apelidados de "bilhetinhos" por opositores seus, em contraposição aos entraves da burocracia. J. Pereira, que trabalhou no setor de comunicação da gestão estadual janista, publicou uma série desses textos em livro. Em seu prefácio, compara tais atitudes a um experimento político de prestígio internacional, a ações do ex-primeiro ministro britânico Winston Churchill que: "Ao contrário dos ofícios formais, redigidos em linguagem empolada, cheia de circunstâncias [...] passou a formular ordens incisivas, com o número mínimo de palavras, encaminhando-as, não através dos escaninhos da burocracia britânica, tão nefasta quanto a nossa, mas diretamente à autoridade, civil ou militar, a que se destinavam"20.

De forma semelhante, Jânio era tratado como alguém que tinha equilibrado as finanças no estado de São Paulo. Este atributo era partilhado entre ele e Carvalho Pinto, seu Secretário das Finanças, que o sucedeu como governador. Na campanha presidencial de Jânio, ambos estavam "umbilicalmente" associados. É o que pode ser notado nos comentários do jornalista Jorge Ferreira sobre o Plano de Ação, programa da administração Carvalho Pinto, veiculados na revista $\bigcirc$ Cruzeiro em primeiro de agosto de 1959. Tal orientação política é tida como um "notável progresso no método de governar" por abandonar o empirismo, a improvisão, o compadrismo e "ater-se a um racionalismo sistemático e a um realismo alentadoramente frio"21. Esses métodos são tratados como uma continuidade em relação às administrações anteriores de Jânio, afirmando-se: "Batendo a corrupção, saneando, removendo entulhos, destocando, matando pragas aqui e deitando boas sementes acolá", fez com que "onde reinava o caos voltou a ordem, onde açoitava a tempestade voltou a bonança"22.

Essas questões tocam no velho problema da imagem pública de governantes nas democracias ocidentais. Peter Burke observa que, com o fim de muitos regimes 
monárquicos na Europa, as convenções do retratismo real tiveram de adaptar-se a temas como progresso, liberdade, modernidade, igualdade e fraternidade. Uma das soluções propostas para isso é bem representada em um quadro de Napoleão Bonaparte produzido por Jacques-Louis David (1748-1825). Nele, nota-se o célebre líder pintado em seu escritório, ao lado de uma vela acesa e de um relógio marcando quatro horas e quinze minutos. Dessa forma, o governante aparece como o burocrata, empenhado logo cedo em sua mesa de trabalho. Esse retrato foi fonte de inspiração para a representação de outros governantes, identificados com distintas orientações políticas, desde Stalin em seu escritório, de Fedor P. Reshetnikov, até Luís XVIII em seu gabinete, de François Gérard ${ }^{23}$. Esse cânone também terá sua versão na formulação da imagem pública de Jânio: em meio à descrença generalizada nos políticos e na administração pública, ele se apresenta, e é representado, como o burocrata.

Em contraposição, os adversários de Jânio apontavam o que seriam as ambiguidades dele. Acusam-no de assediar sexualmente funcionárias públicas e de frequentar o número 227 na rua Martins Fontes, onde participaria de farras noturnas com "as jovens Alcira Peluça, judia brasileira, e Iracema Vitória, Uruguaia"24. Em tais circunstâncias, segundo Viriato de Castro, foram mobilizadas conhecidas imagens e caricaturas para depreciá-lo ${ }^{25}$. Republicaram a célebre foto em que sua imagem é congelada sobre a tribuna da Câmara Municipal de São Paulo, com a barba crescida, descabelado e o "olhar místico". Os insultos a ele dirigidos eram os mais diversos: "mistificador", "vassourinha", "anormal", "louco", "tarado", "desequilibrado", "caricato", "clown", "Calvero sem talento"26, "Harold Loyd em decadência", "falso Judas", "Madalena descabelada". Tais qualificativos, de forma geral, evocam a figura do bufão, tão presente em sua carreira política. Nesta versão, porém, ele é tido como alguém desequilibrado, sem o controle de si.

Enfim, dubiedade de comportamentos, atributo que passam a conferir-the com frequência. Como no caso de Edmundo Monteiro, diretor do Diário da Noite, processado por Jânio por ter publicado matéria considerada ofensiva; mais especificamente, na defesa do jornalista, feita na Assembleia Legislativa pelo deputado Cassio Ciampolini, do PTB, durante a qual comentou o conteúdo da referida reportagem, ilustrada pela justaposição de duas fotos:

A primeira delas mostra o Sr. Jânio Quadros com um velho capotão surrado, gasto e até pouco limpo; a gravata desmanchada no colarinho, rasgando, da tribuna da Câmara, um convite do Jockey Club, porque jamais poria os pés em clube que não pagasse impostos. A segunda fotografia mostra o Sr. Jânio Quadros de hoje: de casaca, de cartola e de comenda, elogiando o Jockey Club. É uma incoerência da parte do Sr. Governador ${ }^{27}$.

Ao que parece, uma referência à etimologia do nome do governador oriundo de Janus, divindade romana com duas faces - transformou-se em instrumento privilegiado da luta política.

Esse tipo de representação, porém, não era incontornável para ele ou para seus simpatizantes no debate público. Na Figura 4, por exemplo, há uma tentativa de conciliar os supostos aspectos dúbios de sua personalidade, dando-thes um sentido positivo. Trata-se de uma das charges publicadas em Jânio e a volta ao mundo, de
23. Cf. Peter Burke (2004, p. 86).

24. Cf. Viriato de Castro (1959, p. 175).

25. Idem, p. 172-173.

26. Frantisek Verdoux Calvero, imitador de Charles Chaplin; no Brasil desde 1968.

27. Cassio Ciampolini,Diário de São Paulo (1 nov. 1957), apud Vera Chaia (1991, p. 146). 
Maurício Vita e Mauro Escobar, em 1959. Nele, os autores representam de forma cômica a viagem que Jânio fez a vários países antes do início oficial de sua campanha presidencial. A cena remete à sua partida a bordo de um navio. Ele é representado num dos corredores da embarcação sentado ao lado de D. Eloá, sua esposa. Em pé, e de costas para o casal, aparecem duas mulheres em trajes de banho. Em provável brincadeira com o estrabismo de Jânio, um de seus olhos é dirigido para as moças e o outro para um "Tratado de Economia", em suas mãos. Nos dizeres dele para sua mulher, um duplo sentido: "Eloá, meu bem, nessa 'matéria' eu sou especialista". Por isso não sabemos exatamente se ele é um profundo conhecedor do corpo feminino, de economia, ou de ambas as coisas. Desvinculada do conjunto da obra, tal ilustração pode até ganhar foros de crítica ao comportamento de Jânio. Se colocada, porém, ao lado do conjunto das charges, francamente favoráveis a ele, ela bem pode ser um manifesto de que suas supostas qualidades de administrador racional não colidem com suas fraquezas humanas.

E também não faltaram aqueles que apontassem, na mudança nos comportamentos de Jânio, um aprendizado no controle das emoções. É muito significativo, por exemplo, o modo como o jornalista David Nasser - em seção da revista $\bigcirc$ Cruzeiro, na edição de 19 de novembro de 1960 - narra a quinta vez que

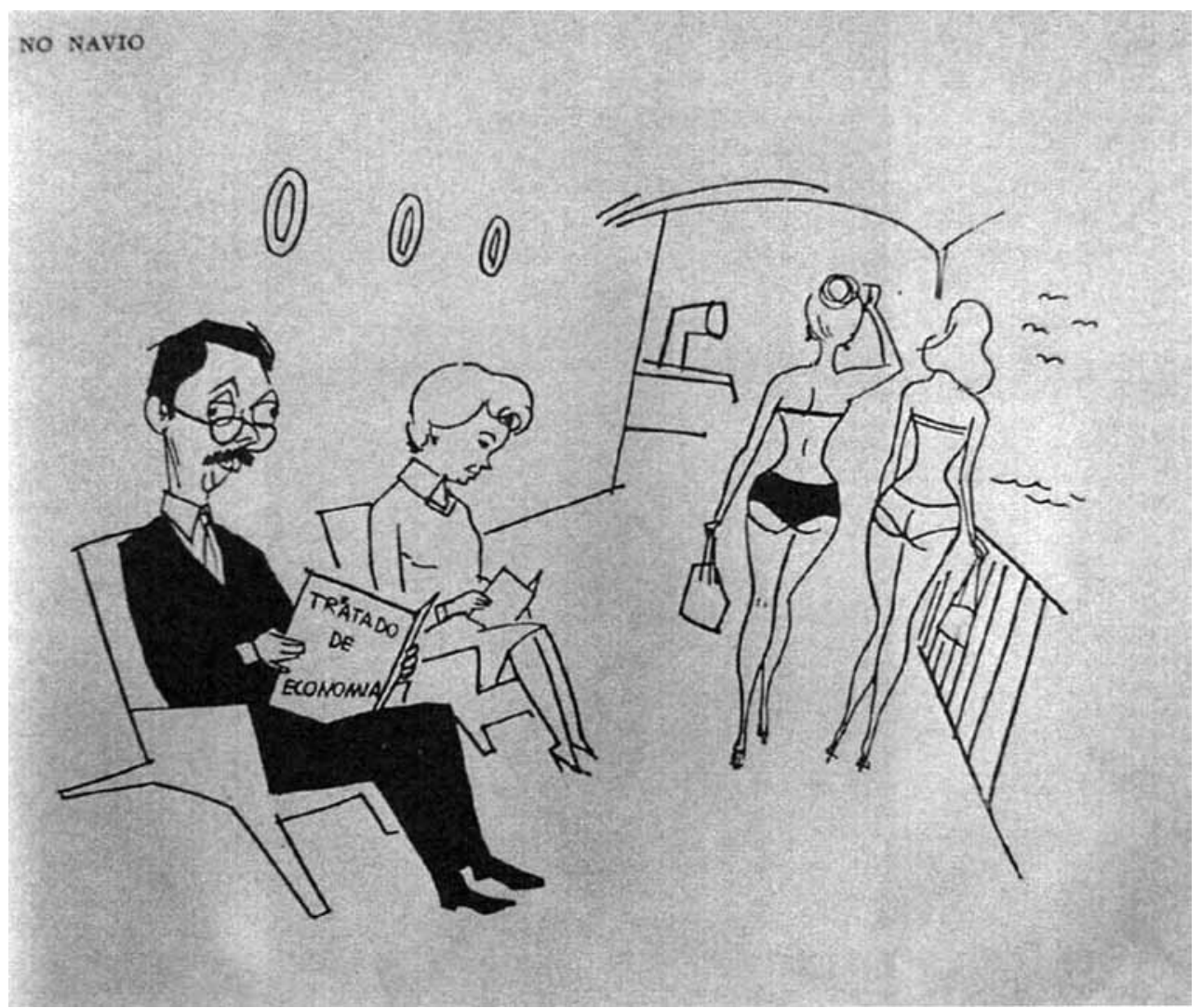

Figura 4 - $\bigcirc$ especialisła. Maurício Vita \& Mauro Escobar (1959, p. 21 ). 
o encontrou. Ao constatar que ele vestia terno sob medida e que se apresentava de forma elegante, mostra surpresa por não ter se deparado com o personagem "desgrenhado, nervoso, largado, fremente, vulcânico" de outrora; ao invés disso, era "uma força domada, uma natureza vencida". E questiona-se:

Qual dos dois, pensei, será o autêntico? $\bigcirc$ Jânio despenteado, de colarinho aberto, barba por fazer, levando para os comícios um rato dentro duma gaiola, um Jânio que conduzia nas viagens uma bagagem especial de roupas para comício - ou esse Jânio calmo, tranqüilo, ponderado, que sorria mansamente, que bebia discretamente o seu vinho? Aquele era o cachaça. Este era o champanha ${ }^{28}$.

Tal dúvida sobre a autenticidade de sua personalidade podia ser contestada, ao representarem-no como alguém que efetivamente aprendera a se conter. A justaposição de fotos da Figura 5, veiculada na revista $\bigcirc$ Cruzeiro, em 11 de fevereiro de 1961, incumbe-se dessa tarefa. À esquerda, ele aparece como vereador, com a barba crescida e o cabelo solto e vestindo um capote; à direita, em momento posterior de sua carreira, com a barba feita e o cabelo engomado e trajando um terno. As palavras sobrepostas nas imagens interligam-nas, ao sugerir que Jânio se tornou um
28. Cf. David Nasser (1960, p. 4-5).

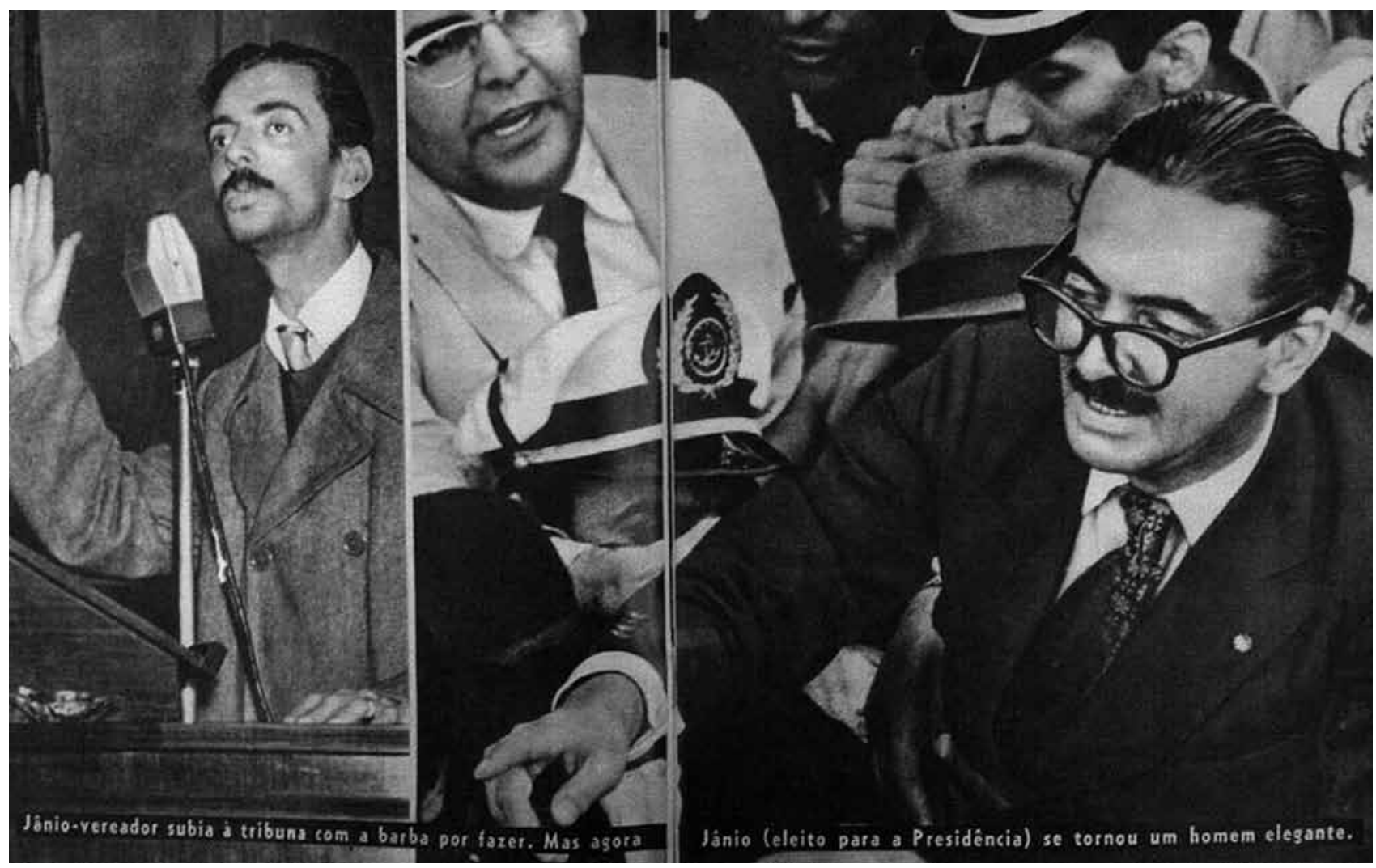

Figura 5 - Do grotesco à elegância. Fonte: O Cruzeiro (1 1 fev. 1961, p. 10-1 1).

Annals of Museu Paulista. v. 19. n.1. July.-Dec. 2011. 
homem elegante, fornecendo uma ordem e um sentido para a leitura: houve uma mudança na apresentação pública dele, e o cuidar mais de si denota mais autocontrole.

E o que isso teria a ver com a administração pública? A Figura b, em que é sobreposto um retrato de Jânio com os cabelos engomados e a vestimenta alinhada, talvez nos ajude a esclarecer essa questão. Trata-se de ilustração impressa em uma toalha e distribuída no país pela empresa Vulcan Material Plástico S.A., tendo tal estampa circulado também em anúncios nas revistas Manchete e $O$ Cruzeiro. Nela, é visível uma homenagem à vitória de Jânio nas eleições presidenciais - já com a pretensão de ser um "documento histórico". Em seu entorno são vistos, como indica a legenda, elementos que procuram ilustrar a plataforma de governo dele. Numa imagem rica em detalhes, podem ser notados elementos como uma balança, livros, um globo terrestre, instrumentos de desenho técnico, uma aquarela acompanhada de pincéis, um trator numa paisagem rural, produtos agrícolas, uma estrada, as comportas de uma represa, postes para a

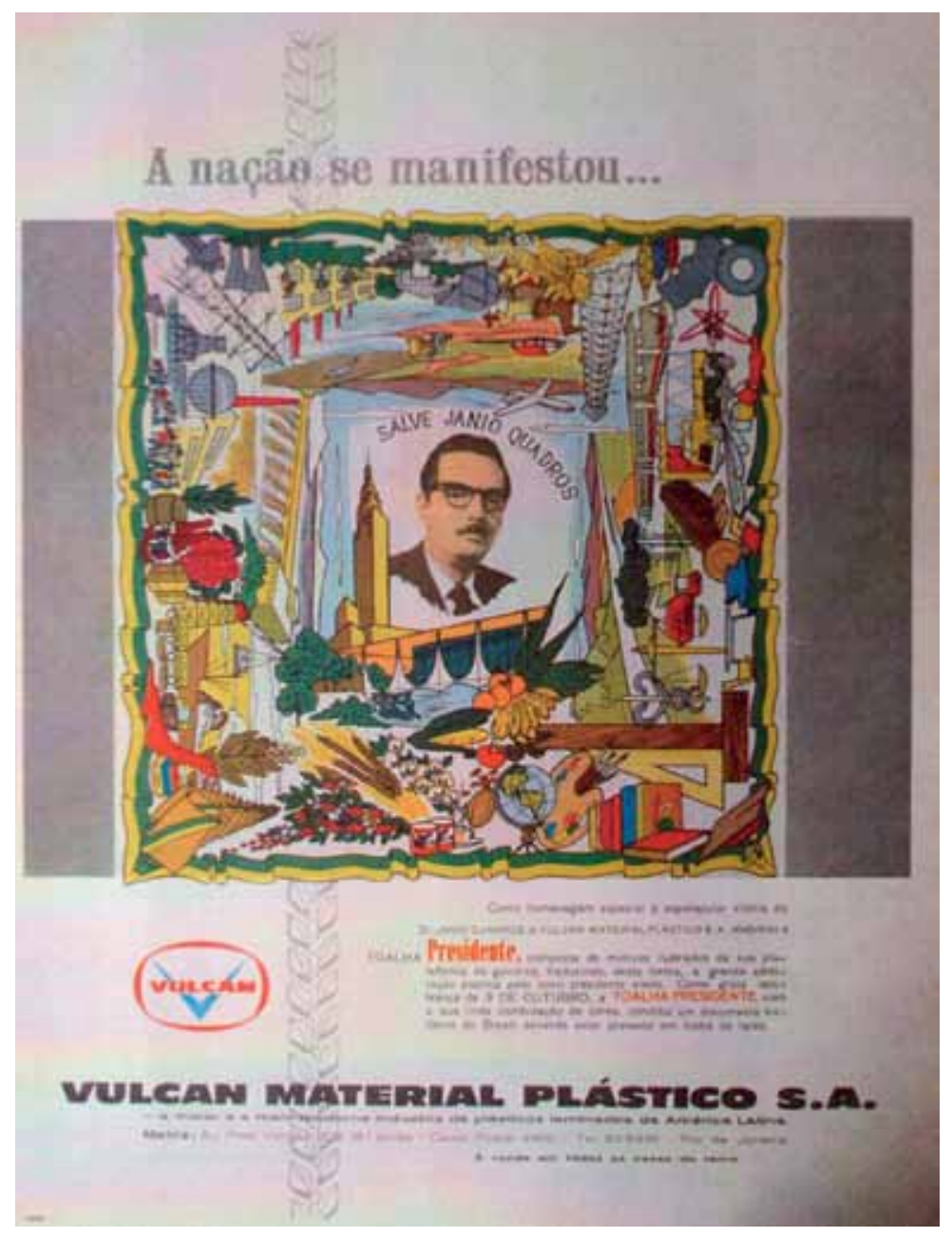

Figura 6 - $\bigcirc$ intérprete das forças históricas. Fonte: Manchete (19. nov. 1960, p.211. 
sustentação de fios elétricos, prédios com chaminés, recipientes utilizados para experiências químicas, um caminhão, um trem, um avião, um navio e edifícios.

Tais figuras parecem ser atributos da justiça, das artes, da educação, da agricultura, da indústria, da infraestrutura e da construção civil. E o escrito na parte superior do anúncio - A nação se manifestou... - encarrega-se de interligar a figura de Jânio a esses elementos, apontando-o como uma opção política a eles associada. Com isso, o tema central da ilustração trata do controle da natureza e da transformação do país numa nação moderna e industrializada, com um claro sentido de progresso; e o novo presidente é representado como o condutor dessa mudança. Mensagens politizadas como essa, como seria de se esperar, foram sistematicamente desqualificadas pelos adversários e inimigos dele.

New look para o planalto

Ainda outros símbolos e mensagens com significados políticos gravitaram ao redor da imagem pública de Jânio. Em seus últimos momentos como governador, ele se empenhou na articulação de sua candidatura para deputado federal pelo Paraná, pela legenda do PTB. Nas eleições de 3 de outubro de 1958, após alguns comícios naquela região, conseguiu os votos de 78. 810 eleitores, a maior votação proporcional do estado. Não participou de nenhuma sessão do Congresso, preferindo empreender uma viagem ao exterior para articular sua candidatura presidencial. Em seu périplo, percorreu lugares como África do Sul, Japão, Turquia, Egito, Israel, lugoslávia, União Soviética e outros países da Europa Ocidental.

Durante a viagem, Jânio deparou-se com o desafio de questionar as acusações de seus adversários de que planejava liquidar a democracia e entregar o país à ação irrefreada dos monopólios internacionais. Veja-se, por exemplo, o que o líder comunista Luiz Carlos Prestes afirmava no livreto Por que os comunistas apoiam Lott e Jango, escrito naquelas circunstâncias ${ }^{29}$. Ele menciona episódio ocorrido em 1955, quando Jânio, então governador de São Paulo, apoiou um movimento para impedir a posse do presidente eleito, uma "conspiração golpista e entreguista" para facilitar a ação dos "agentes do imperialismo norte-americano"30. E a afinidade do candidato com tais propósitos é apontada a partir de uma de suas entrevistas ao jornal Correio da Manhã, em que teria se posicionado contra o monopólio estatal do petróleo.

Diante dessas questões, como fizera outras vezes, Jânio serviu-se de símbolos para indicar seu comprometimento com a soberania do país, desta vez os slacks indianos. Na Figura 7, em retrato de autoria de Ernesto Santos, veiculado na revista $\bigcirc$ Cruzeiro em 11 de julho de 1959, ele está em Istambul vestindo um desses trajes. Sua imagem é congelada em seu gesto de puxar os olhos levemente para baixo com os dedos indicadores. Segundo a legenda, Jânio, com "roupa à Nasser", está atento diante do petróleo como um dos alicerces da soberania nacional. Ocorre então a associação de sua imagem a um dos ícones do mundo árabe: Gamal Abdel Nasser. Este, à frente do governo egípcio, nacionalizara o canal de Suez havia pouco, diante
29. Ver Luiz Carlos Prestes (1960).

30. Trata-se de referência a episódio ocorrido em reação ao "contragolpe preventivo" encabeçado pelo General Lott em 1955, para assegurar a posse do presidente eleito. Inconformados com essa situação, figuras como Carlos Lacerda e o presidente interino Carlos Luz embarcaram no cruzador Tamandaré, a partir de onde pretendiam liderar um movimento de resistência. Planejavam desembarcar em Santos, com o apoio do então governador de São Paulo, Jânio Quadros. 
da pressão contrária de potências ocidentais, como Inglaterra e França, interessadas no controle daquele acesso marítimo. Desse modo, tanto Jânio quanto o trabalho de edição da revista parecem convergir no sentido de veicular a imagem de um líder à altura de confrontar poderosos interesses internacionais, especialmente na questão da manutenção do monopólio estatal do petróleo.

A escolha do slack para veicular essa simbologia, é preciso lembrar, foi feita em meio a outras possibilidades. É o que indica carta de Castilho Cabral, um dos principais organizadores da campanha de Jânio. Em 2 de julho de 1959, data próxima daquela em que o referido retrato foi feito, ele sugere a este último o seguinte: "Os nossos adversários querem a sucessão em termos de 'nacionalismo vs. entreguismo' não só para terem bandeira, como também para neutralizar o sentido da 'vassoura' [...] afigura-se-me que um impacto emocional (v. lambuzando as mãos no 'ouro negro' em poço do Recôncavo, como outro dia lembrara o C. Lacerda em casa do Brigadei-

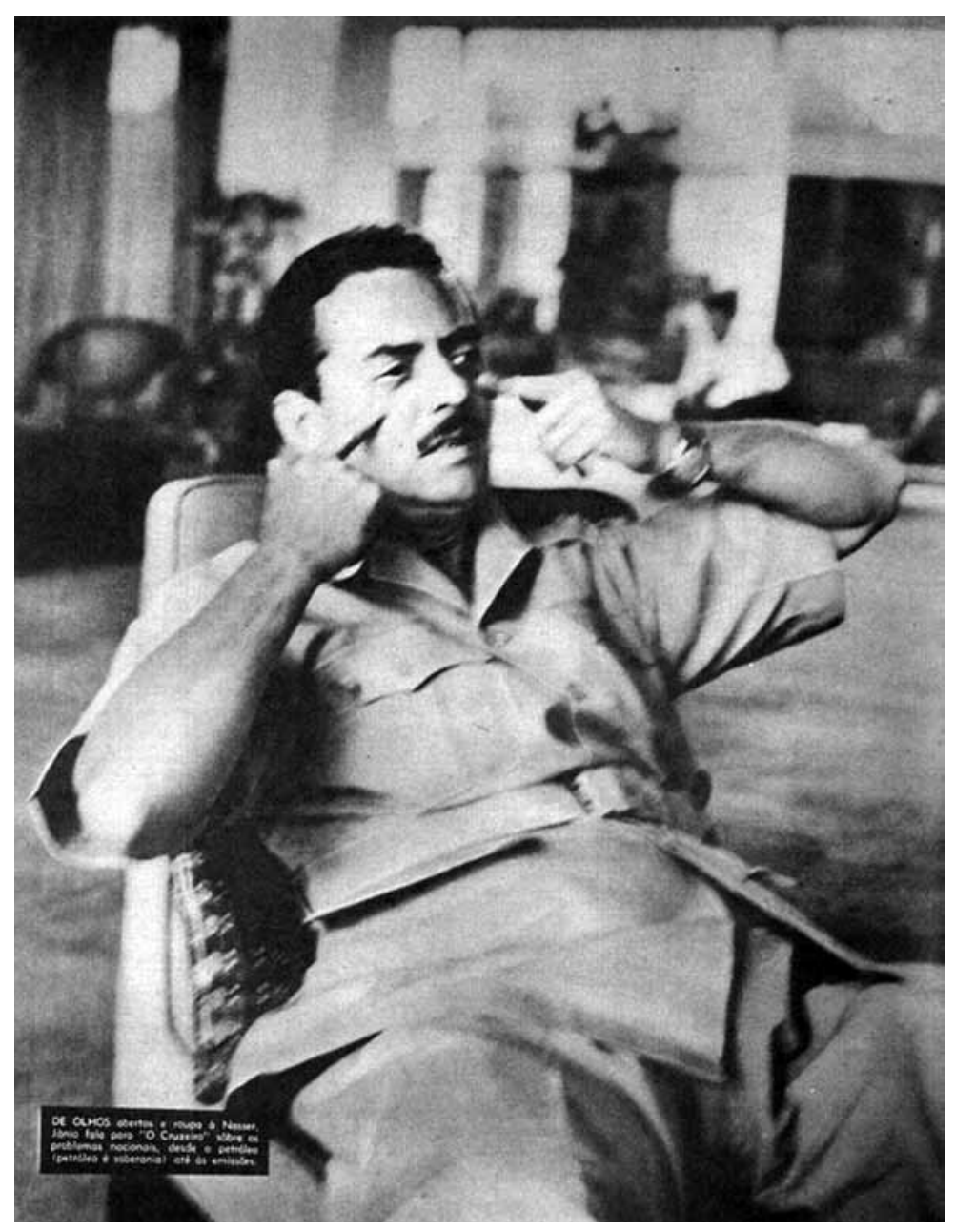

Figura 7 - Jânio à moda de Gamal Abdel Nasser. Fonte: O Cruzeiro 111 jul. 1959, p. 43). 
ro Muniz) liquidaria o assunto" ${ }^{31}$. Trata-se de uma referência a um célebre gesto de Getúlio Vargas cujo retrato foi reproduzido na imprensa durante a década de 1950, símbolo de soberania obtida com a defesa das riquezas naturais do país ${ }^{32}$.

Ao que tudo indica, a opção pelo slack está relacionada à tentativa de Jânio em dissociar sua imagem pública do legado varguista (representado pela administração Kubitschek), pelo menos de forma direta, apresentando-se como um candidato de oposição. Ademais, tal vestimenta sinalizava o projeto da chamada Política Externa Independente (PEI) $)^{33}$. Os entusiastas desta defendiam a ampliação dos mercados para os produtos fabricados no país em regiões como o Leste Europeu, a Ásia e a África, o que, de certo modo, o governo Kubitschek já vinha fazendo. Entre os princípios desse projeto, advogava-se que não havia razões para o Brasil deixar de empreender trocas comerciais com países de regiões periféricas ou de orientação comunista; e que o país não deveria alinhar-se a nenhum dos dois polos da Guerra Fria, liderados por Estados Unidos e União Soviética. No centro dessas preocupações residia o princípio de autodeterminação dos povos. Daí a alusão a Nasser: referência dos países do chamado Terceiro Mundo em busca de maior autonomia diante das grandes potências.

Uma orientação política dessa natureza, é de se supor, contrariava interesses de grupos alinhados à política externa norte-americana. E não é difícil imaginar como suas diretrizes poderiam ser atacadas por serem supostamente lenientes ou simpáticas em relação ao comunismo. Com o intuito de evitar isso, no dia primeiro de agosto de 1959, Castilho Cabral escreveu a Jânio propondo-lhe medidas preventivas a respeito da repercussão da estadia dele no Leste Europeu: "Em vista de sua visita à Rússia, creio que não será mau que eu acerte com o C. Lacerda um 'Te Deum' aqui na Candelária, ou então, V. acerte com o CP [Carvalho Pinto] e Quintanilha um em S. Paulo, pois que, desde a minha surra senatorial, tenho muito medo da influência das batinas" 34 . Simbologias cristãs pareciam ser um antídoto eficaz contra acusações de comunismo.

Pouco antes, Jânio procurara investir seus slacks justamente com tais significados. É o que transparece no conjunto de fotos da Figura 8, também de Ernesto Santos. Nas tomadas, o candidato é retratado na Terra Santa portando um daqueles trajes em momentos em que procura se apresentar como devoto. Assim, se o uso do slack fora feito antes com o intuito de transmitir a ideia de defesa dos interesses nacionais, surge então para representar o quanto essas diretrizes se harmonizavam com símbolos cristãos. E provável que essa encenação tenha sido deliberadamente articulada por Jânio e membros de sua equipe, com o propósito de afastá-lo de acusações de estar envolvido com o comunismo e seus princípios materialistas. Afinal, além do risco à sua candidatura que representavam suas visitas a países em que vigoravam regimes inspirados em tal doutrina, ele manifestara a pretensão de manter certa presença do Estado na economia: princípio então caro aos países comunistas. Não se pode esquecer também que ele se propunha a defender ideário inspirado na democracia cristã, assim como fizera no início de sua carreira política, ao propor a valorização do homem no âmbito do processo de desenvolvimento econômico; daí as referências religiosas ${ }^{35}$.
31. Cf. Castilho Cabral (1962, p.261-262).

32. Em 21 de abril de 2006, o então presidente Lula repetiu o gesto deVargas. Durante evento de início da exploração da plataforma P-50, na bacia de Campos, mergulhou as mãos em petróleo e exibiu-as aos fotógrafos. Logo depois, manchou deliberadamente os trajes de Dilma Rousseff, sua Chefe da Casa Civil, como que simbolizando a delegação de seu suposto compromisso em defender os recursos naturais do país àquela que queria como sua sucessora.

33. Cf. Braz J. de Araújo (2000, p. 264).

34. Cf. Castilho Cabral (1962, p. 270).

35. Cf. Miriam L. Cardoso (1978, p. 306) 
36. Ver Roland Barthes (1957).

37. Ao analisar os discursos de Jânio durante a campanha presidencial e o período em que ele ocupou a Presidência, Miriam Limoeiro Cardoso destaca que:"Para o Presidente Jânio Quadros o presente não aparece como um dado. O estado de coisas com que se defronta não é tratado como uma situação de fato a que deva dar continuidade ou que tenha de aceitar como ponto necessário de partida. Não me refiro aqui ao presente como o atraso ou o desenvolvimento do País, mas ao processo de desenvolvimento em curso, na sua forma e na sua mecânica. Jânio praticamente se insurge contra ele, submetendo-o a severa crítica e, participando de suposições diversas, propõe caminhos diversos"; cf. Miriam L. Cardoso (1978, p. 287). Dessa forma, mesmo admitindo que, ao não se reduzir à reprodução de sentidos definidos pela escrita ou pela fala, as fontes iconográficas tenham um estatuto próprio, fica evidente que, em termos de politização, não devam nada às outras fontes.
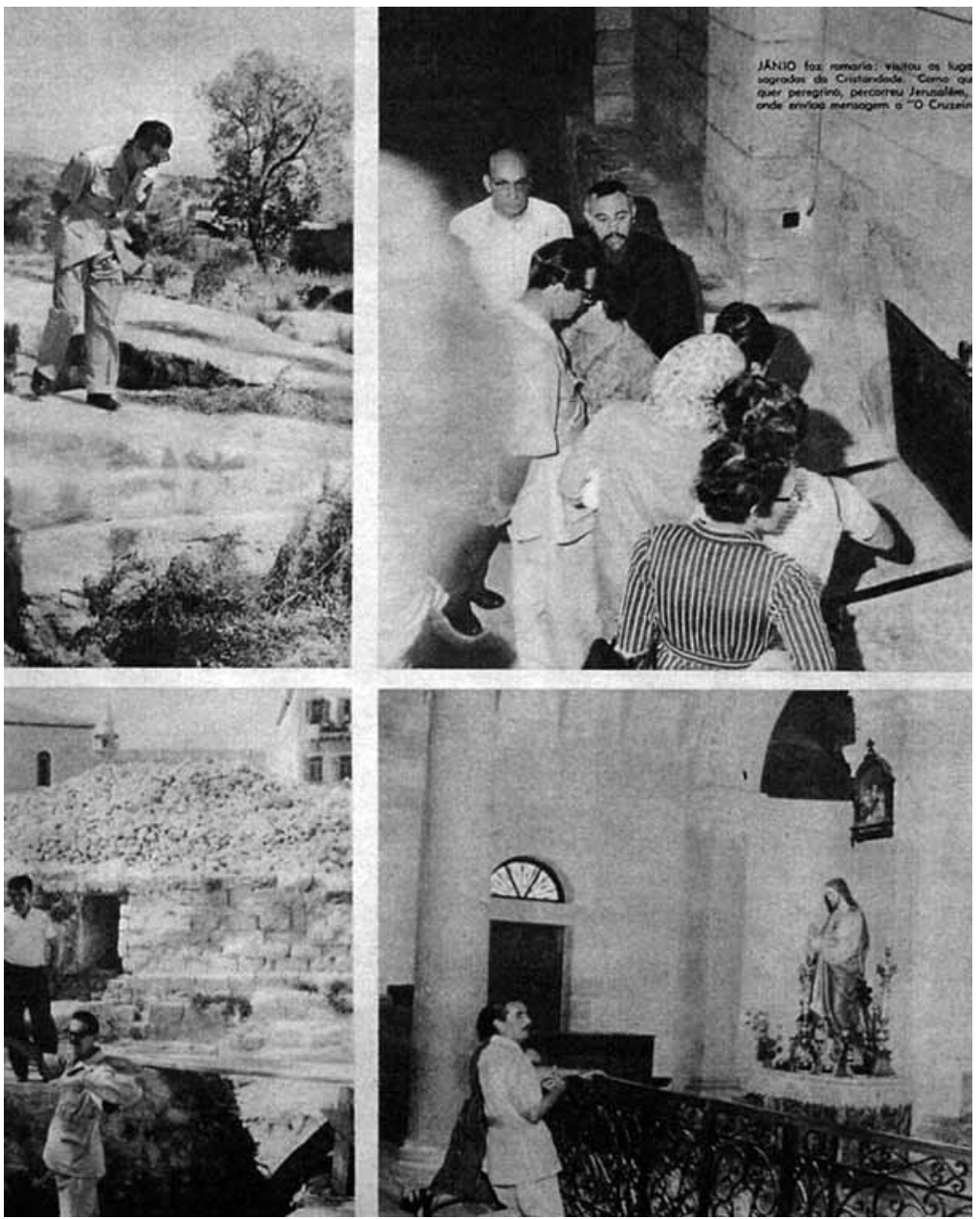

Figura 8 - Cenas de devoção. Fonte: O Cruzeiro 11 jul. 1959, p. 47).

Produção em série de mitos por meio de imagens? Um célebre ensaio de Roland Barthes, publicado na coletânea Mythologies, ajuda-nos a refletir sobre essa questão ${ }^{36}$. O texto analisa uma capa da revista francesa Paris-Match, em que aparece um soldado negro com uniforme francês prestando continência à bandeira tricolor. Segundo o autor, essa composição é uma alusão ao colonialismo francês: a França seria um grande império em que todos os seus filhos, independentemente da cor, servem-na fielmente. O mito assim constituído não nega as coisas; ao contrário, sua função é expressá-las. Seu papel exprime-se na purificação delas, quer dizer, no esvaziamento do seu sentido contingente e histórico e em sua fundação enquanto natureza. Ora, retomando o caso das imagens de Jânio, o que se observa não é justamente o inverso? Ou seja, mensagens que procuram desnaturalizar determinadas condições do país, tidas como passíveis de transformação por meio de projetos políiticos específicos? ${ }^{37}$ Dessa forma, se havia a produção de um mito em torno de Jânio, isso não implicava na despolitização generalizada de suas imagens. 
Possivelmente nem mesmo em momentos em que apenas sua vida privada era representada. Veja-se, por exemplo, matéria publicada em 15 de outubro de 1960, na revista $O$ Cruzeiro, por José Amádio. Nela, há a proposta de fornecer um retrato do "lado humano" de Jânio. De início, uma transformação logo é notada: "Por motivos que ainda não descobri, era inimigo da navalha e do pente [...] $\bigcirc$ Jânio de hoje, mudou ou foi mudado. Era barbudo, está escanhoado. Era pálido, está rosado. Era triste, está alegre. Era encurvado, está ereto [...] Apresenta-se sempre bem barbeado, bem penteado, bem escovado, bem passado"38. Um maior controle de si, que o qualifica para governar outras pessoas. Além disso, não seria pai nem marido autoritário, o que o qualificava para conduzir um regime democrático. Colocou "nomes bem brasileiros" em seus cachorros, como Guri e Totó, sinal de que teria em alta conta a cultura nacional. Lia histórias em quadrinhos, ao contrário do que se poderia esperar de um político sisudo. Enfim, alguém com hábitos simples e comuns, que seria capaz de sensibilizar-se com os problemas alheios.

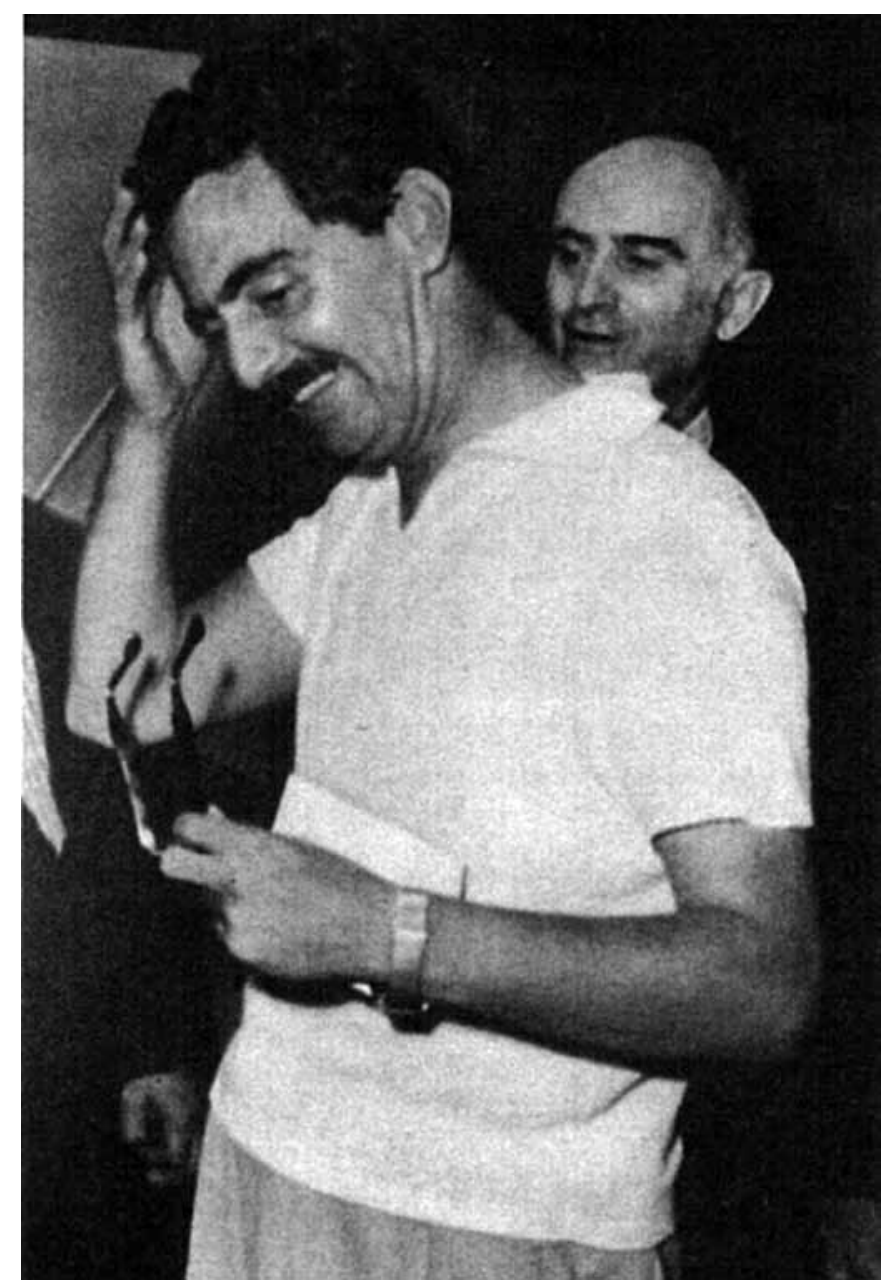

Figura 9 - Jânio de carne e osso. Fonte: O Cruzeiro (15 out. 1960, p. 14-15).

38. Cf. José Amádio (1960, p. 14-15). 
41. Cf. Castilho Cabral (1963, p. 185).
O retrato publicado junto desse texto, na Figura 9, deve ser interpretado no conjunto da matéria. Antes de mais nada, desconhecemos sua autoria até o momento. Nele, Jânio surge de camiseta esporte branca, com os óculos numa das mãos e a cabeça levemente inclinada para baixo, ao mesmo tempo em que sorri e leva a outra mão à cabeça. Estas alusões a comportamentos informais e descontraídos, ao que tudo indica, foram utilizadas pelo trabalho de edição da revista para corroborar a proposta do colunista de apresentar o "lado humano" da pessoa pública. Na formatação final, porém, tal imagem expressa mais do que isso, ao trazer a mensagem de um líder despindo-se de seu envoltório de político e apresentando-se como cidadão comum.

Tal mensagem pode ter sido importante para conferir credibilidade às propostas da democracia cristã por ele veiculadas. Essas insistiam na necessidade de se abandonar o que seria a frieza do modelo de desenvolvimento então em voga, tido como demasiadamente centrado em números e em desempenho econômico. Em seu lugar, seria implementado um desenvolvimento sensível aos problemas das pessoas em geral, com o homem no centro de suas preocupações. E nada melhor para reforçar essa hipótese do que a carta de uma leitora das colunas de José Amádio, publicada na mesma edição da revista $O$ Cruzeiro. Nas palavras de Rosa Schulte, uma "coisa revificante" acontecia quando lia os textos daquele autor:

\begin{abstract}
Sentimos ser uma partícula deste mundo, descobrimos que também, quem sabe, possuímos qualidades positivas e poderíamos-nos aproximar daqueles que apenas se acham distanciados de nós pelas circunstâncias de nossas vidas, mas aos quais estamos unidos pelos mais estreitos laços de fraternidade. Quebra-se então a camada de gelo na qual nos havíamos encarcerado e libertamo-nos da solidão em que nos debatíamos ${ }^{39}$.
\end{abstract}

Representações e imagens da vida privada, de candidatos à Presidência, que pareciam facilitar a adesão de eleitores a projetos políiticos.

Em meio à explicitação de conteúdos programáticos, Jânio e sua equipe podem ter se preocupado também em borrar seus vínculos com o capital estrangeiro. Isso pode ser bem percebido em viagem feita por eles a Cuba. Os preparativos dela são narrados por Paulo de Tarso Santos, na época militante do PDC e assessor da campanha janista. Em sua versão, a credibilidade de Jânio havia sido profundamente abalada por ele ter renunciado a sua candidatura no final de 1959, de modo que urgia desviar as atenções desse acontecimento. Com essa preocupação, afirma que propôs ao candidato uma viagem à itha caribenha, oportunidade que seu amigo, o embaixador cubano, havia the oferecido. Nas instruções dadas a Jânio: "eu acho que você deve mesmo levar o máximo de pessoas possível para testemunhar o que vai acontecer em Cuba. Porque, se você for sozinho, os seus adversários vão dar à viagem a versão que quiserem. E realmente ele convidou a imprensa, foi o [...] Castello Branco, foi gente do Estado de S. Paulo, foi um grupo muito grande de pessoas. E a viagem foi um sucesso"40. Tão importante quanto a viagem era quem apareceria ao lado de Jânio, nas palavras de Castilho Cabral, gente insuspeita de "esquerdismo"41. Este último assevera ainda que, entre os propósitos da ida a Cuba, estavam o combate às ideias 
de que o primeiro era "entreguista" ou lacaio dos "trusts" e a divulgação da PEl. Um dos entusiastas desta última, o diretor do jornal Diário Carioca, teria desempenhado papel decisivo na escolha: "João Dantas abundou nos argumentos, inteiramente favorável à viagem à Cuba [...] Dois a dois, Jânio desempatou - aceitou o convite de Fidel Castro" 42

Se havia intenções de ofuscar o suporte do capital estrangeiro à candidatura janista, não faltaram vozes que expuseram tais vínculos ao debate público. É o que faz o deputado pessedista Anísio Rocha ao discursar na Câmara dos Deputados em 6 de abril de 1960. Ele endereça repreensões a falas de Jânio durante a viagem a Cuba, seja por ter criticado os norte-americanos, seja por ter declarado que viajava sem gastar nenhum dinheiro, a convite do governo cubano. Tendo como suporte declaração do embaixador de Cuba, o deputado destaca que toda essa retórica era acompanhada pelo financiamento da referida jornada pela empresa multinacional Standard Oil. Assim, ao comentar as fotos de Jânio ao lado de Fidel Castro e Che Guevara, amplamente divulgadas na imprensa, procura desconstruir possíveis sentidos atribuídos a elas:

A identificação do ex-governador de São Paulo como entreguista, como inimigo do desenvolvimento nacional, não será apagada da mente dos nacionalistas sinceros do Brasil pelo simples fato de, em sua semana de recreio em Cuba, Jânio se deixe fotografar ao lado de conjuntos folclóricos daquele país e acaricie as barbas dos revolucionários de Fidel Castro, na vã esperança de trazer, no bolso do colete, um diploma com o timbre da Sierra Maestra ${ }^{43}$.

De qualquer forma, nas eleições de 3 de outubro de 1960, Jânio venceu, com 5. 636. 623 votos; o Marechal Lott conseguiu 3. 846. 825; e Adhemar de Barros, 2. 195. 709. Na Presidência, o primeiro continuou a suscitar debates e polêmicas em torno da simbologia de suas imagens. Adotou os slacks como vestimenta oficial, aparecendo em público e deixando-se fotografar com eles. E chegou a propor aos funcionários públicos que os usassem. A respeito dessa medida, o jornalista Pompeu de Sousa, em paródia dos bilhetinhos de Jânio, publicou um texto no jornal Diário Carioca, em 21 de março de 1961. Para ele, tal ato fazia parte das tentativas do presidente em se apresentar publicamente como onisciente, onipresente e onipotente. E conjectura ainda: "Por enquanto, em caráter facultativo, pois não the passa pela cabeça que, oferecendo tal oportunidade a pobres mortais 'barnabés' de se vestirem à sua imagem e semelhança, Excelência, possa, haver algum [...] capaz de desvalerse de tão insigne faculdade. Mas o caso é que, se tal não se der amanhã, pode-se contar que, depois de amanhã, o facultativo se transforma em obrigatório, imperativo, compulsório"44. Uma vez que os slacks eram símbolos politizados, relacionados à defesa da PEl ou do monopólio estatal do petróleo, o que teria incomodado tanto o jornalista e as pessoas contrárias a essa medida? Algum outro significado político?

Estava em jogo uma antiga representação de Jânio como governante. $\mathrm{Na}$ Figura 10 aparece uma combinação de fotos atribuídas a Rubens Américo, exibida na revista $\bigcirc$ Cruzeiro, em 1 de abril de 1961. Nela, o então presidente traja um slack enquanto manipula despachos. Ele é representado em poses que destacam sua expressão séria no momento em que olha para a documentação. Ao mesmo tempo,
42. Idem, ibidem.

43. Anísio Rocha (6 abr. 1960). Disponível em <www.camara.gov.br>

44. Cf. Pompeu de Sousa (1987, p. 77). 
45. Ver José Alberto Gueiros (1961).

as legendas dispostas pelo trabalho de edição acrescentam informações, como as declarações de que aquilo seria a rotina diária do presidente, iniciada cedo pela manhã. Tal montagem, como vimos, faz referência à representação dos governantes na condição de burocratas. Com isso, ao propor o uso dos slacks ao funcionalismo estatal, Jânio veiculava toda uma carga simbólica por meio desses trajes. Propunha a dinamização da burocracia estatal por meio do combate ao apadrinhamento e ao absenteísmo em órgãos públicos, o que fizera antes por meio da vassoura.

Não deve ser por menos que o uso do slack parece ter sido amplamente recusado pelos funcionários públicos e apelidado de "piiânio". É claro que, sem uma investigação detalhada das proporções da recusa ou aceitação do uso do traje ao longo do país, uma afirmação desse tipo torna-se muito delicada. Mas, se voltarmos os olhos para a seção de moda masculina da revista $\bigcirc$ Cruzeiro assinada por José Alberto Gueiros em 6 de maio de 1961, onde há uma clara tentativa de retirar da gozação orientações do presidente, temos pistas de que isso efetivamente aconteceu: "a revolução dos guarda-roupas, como toda revolução, tem sido prejudicada pelo ridículo de certas tentativas. [...] o 'piiânio' está ficando para trás, apesar da respeitabilidade do patrocínio. $\bigcirc$ povo não o adotou"45. $\bigcirc$ autor explica isso em termos de estética e funcionalidade: "não era mesmo a solução ideal. $\bigcirc$ cinto retira ao blusão a possibilidade de um arejamento ideal, que vem a ser, justamente, a
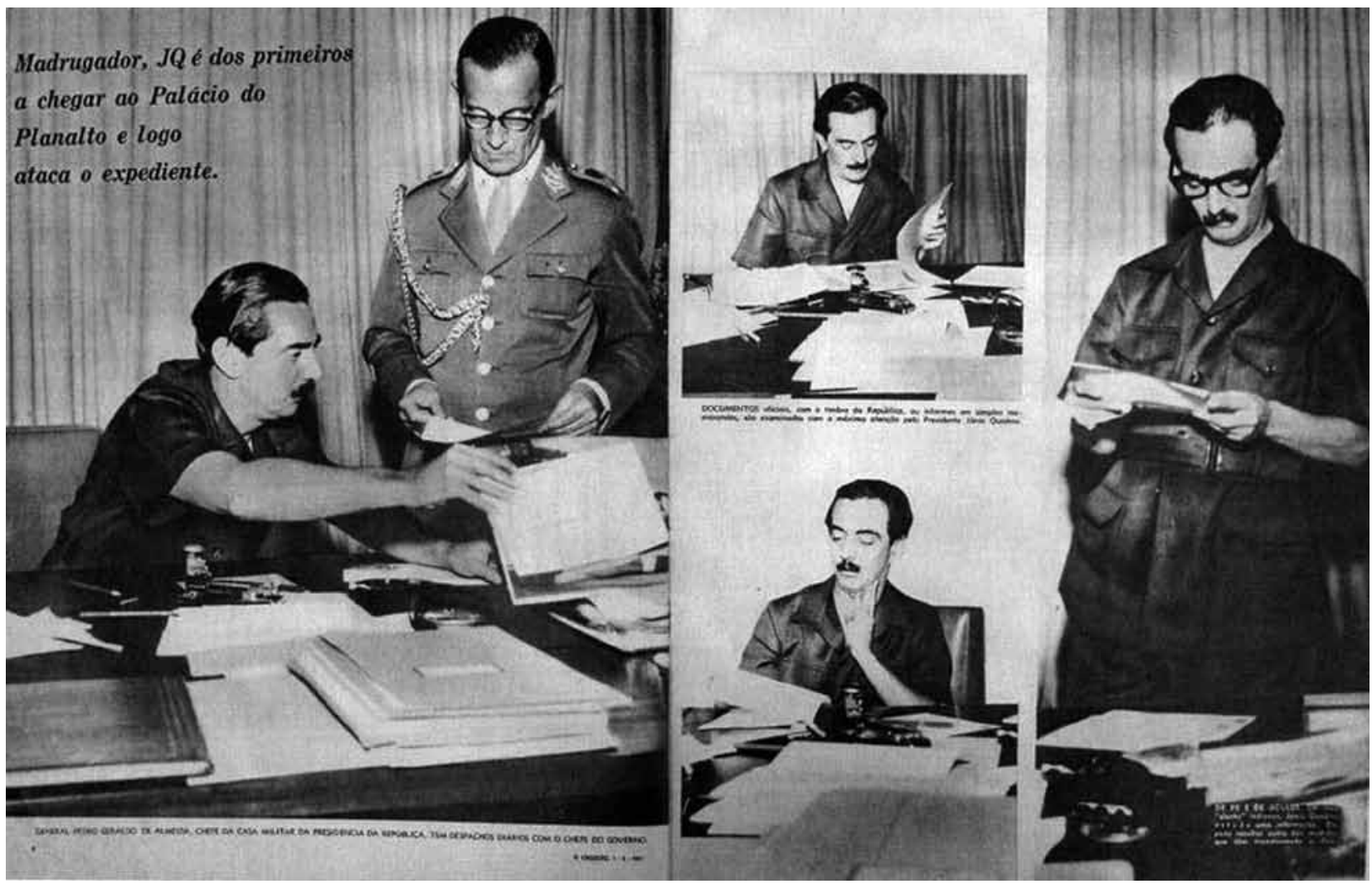

Figura 10 - $\bigcirc$ burocrata. Fonte: O Cruzeiro (1 abr. 1961, p. 8-9). 
vantagem deste sobre o paletó ou a camisa fechada. Seu aspecto militar, a muitos que não são funcionários públicos ou janistas 'enragés', retira o desejo de usá-lo". O que ele perde de vista é a politização da simbologia do slack. Até onde pude apurar, quem adotou a vestimenta foi somente um oficial de gabinete do governo Jânio, o jornalista Raimundo Souza Dantas, depois nomeado pelo presidente como embaixador em Gana $^{46}$. E não é casual que se tratasse de alguém alinhado aos princípios da PEI, simbologia também investida nos uniformes.

Seguindo com seus planos referentes à PEl, Jânio decidiu ampliar seu leque de alianças na América Latina. Em abril de 1961, em Uruguaiana, cidade gaúcha que faz fronteira com a Argentina, encontrou-se com o presidente argentino Arturo Frondizi, e declarou publicamente as intenções de estimular as trocas comerciais e selar o compromisso da defesa do princípio de autodeterminação dos povos entre os dois países. Com base em entrevista feita com Frondizi na década de 1970, o jornalista Flávio Tavares narra a versão do ex-presidente argentino acerca de detalhes da conversa ocorrida entre os dois líderes nos bastidores das negociações. Nela, Jânio teria the proposto a formação de uma frente internacional para a obtenção de maior autonomia em relação aos Estados Unidos: "Quando o presidente Quadros parou de falar, eu tremi.[...] $\bigcirc$ que o Presidente Quadros me propunha era o que eu também desejava e queria em termos pessoais e políticos, mas nem ele nem eu, nem a Argentina nem o Brasil tinham condições" 47 . $\bigcirc$ que parecia estar em jogo era a continuidade ou mesmo o fortalecimento da linha adotada por Jânio em termos de política externa.

É justamente essa perspectiva, porém, que uma das mais famosas representações desse acontecimento (disposta na Figura 11) procura combater. Trata-se de retrato de Jânio feito naquela ocasião pelo fotógrafo Erno Schneider (embora traga a anotação 1962), mas publicado no Jornal do Brasil apenas em 23 de agosto de 1961. Nele, a imagem do presidente é congelada de costas, olhando para o lado esquerdo e, talvez o mais interessante, cada um de seus pés está voltado para uma direção distinta em relação ao outro. Com isso, temos a ideia de que o governante estava desnorteado, sem um rumo certo. Novamente surge o suposto descontrole do corpo de Jânio e as implicações negativas disso para a condução do país. Algumas informações sobre a produção dessa foto podem ser observadas no relato do próprio fotógrafo que a produziu: "O Jânio foi andando... tô do lado dele, sempre, de olho [...] De repente deu uma confusão, estourou um... Um barulho deu uma.... Todo mundo olhou para trás. Ele virou e eu clack, plá, só deu aquela, só fiz uma. Só fiz aquela. Ganhou Prêmio Esso" 48 .

fotógrafo bem pode ter registrado essa cena por obra do acaso, ou por sua argúcia em aproveitar o átimo de segundo para enquadrar cena que já vinha imaginando. De qualquer modo, no processo de atribuição de significado ao retrato, é o trabalho do editor do jornal que parece ter pesado mais, decidindo desarquivá-lo e estampá-lo em momento que julgou oportuno. Exibido em mostra de fotografias promovida pelo Jornal do Brasil em vários aeroportos do país, e publicado com destaque pelo mesmo periódico dois dias antes da renúncia à Presidência ${ }^{49}$, sua mensagem parece ter adquirido o estatuto de explicação satisfatória para este acontecimento, conforme sugere sua premiação em 1962: possivelmente baseada no que a fotografia conteria de profético. Ora, essa representação procurava negar que Jânio tivesse um
46. Cf. Flávio Tavares (2004, p. 172-173).

47. Idem, p. 181

48. Erno Schneider apud Ana Maria Mauad (2007, p. 4).

49. Cf. Silvana L. Silva (2009, p. 264-269) 


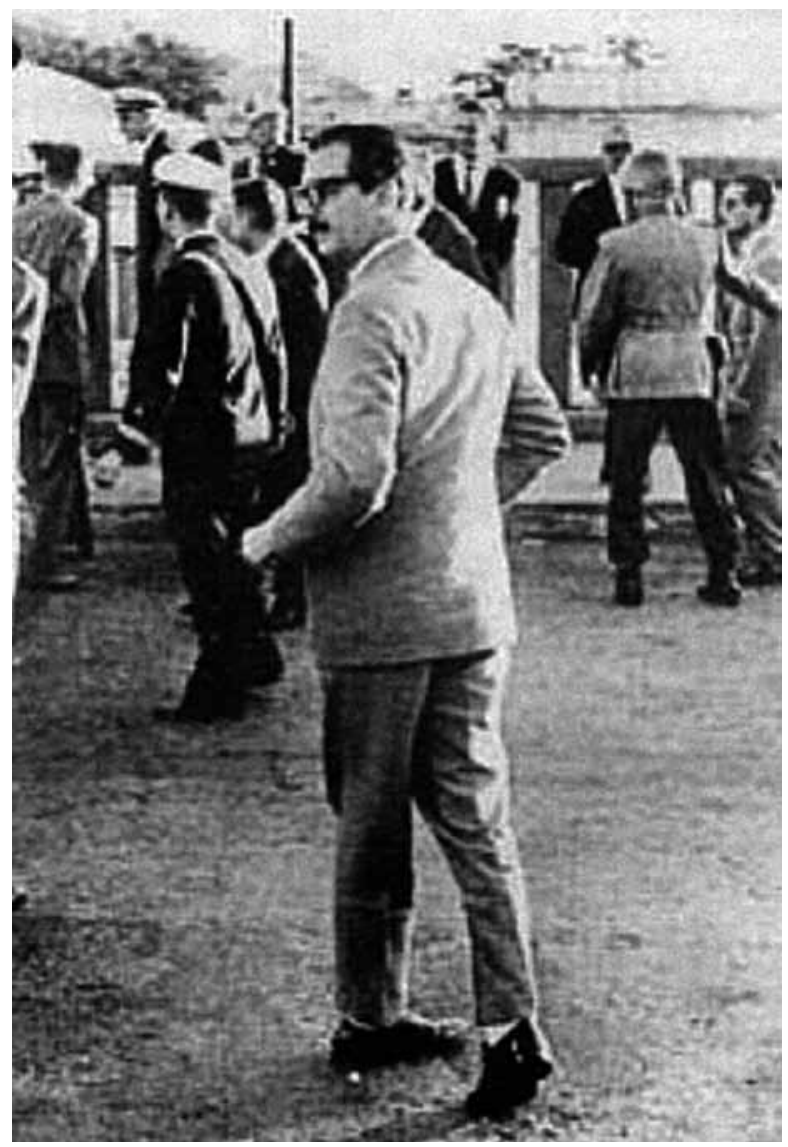

Figura 11 - Qual o rumo? Apud Israel Beloch \& Laura R. Fagundes (2006, p. 29).

rumo para o governo, justamente quando articulava uma política exterior centrada na busca de maior autonomia para o Brasil frente aos Estados Unidos. Mostra de que eram seus adversários e inimigos quem despolitizava as imagens de Jânio.

\section{Considerações finais}

Como vimos, Jânio Quadros esteve vinculado a projetos políticos em diversos momentos de sua carreira política. Projetou-se na políitica paulista com práticas e discursos afinados com a democracia cristã e continuou a defendê-la em sua campanha presidencial; principalmente na questão da melhoria das condições de vida das camadas mais pobres da população, com o intuito de impedir a luta de classes. Também passou a advogar o programa da chamada Política Externa Independente, o qual centrava suas atenções no estabelecimento de relações comerciais com países do Leste Europeu sob regimes de inspiração comunista, da África e da Ásia, pautando- 
se pelo princípio de autodeterminação dos povos. E suas imagens (fossem elas fotografias, charges ou outras formas de iconografia) reproduzidas em larga escala na mídia atuaram na veiculação de mensagens com conteúdos políticos. Eram seus opositores que se esforçavam para obscurecer seus vínculos com quaisquer orientações programáticas, tratando-o, em geral, como desequilibrado e por isso incapaz de governar: interpretação que parece ter-se firmado na memória coletiva após a renúncia à Presidência em 1961, em provável tentativa frustrada de golpe.

Com isso, sem desprezá-lo, espero ter relativizado o peso do personalismo de Jânio na consolidação de sua força política, tão abundante na historiografia. Seus ternos amarrotados, suas gravatas tortas e sua gesticulação vivaz eram não apenas recursos para se assemelhar ao eleitorado mais humilde, como também instrumentos para a mobilização de paixões coletivas, em especial a cólera. Jânio encarnou por diversas vezes o personagem imaginário do bufão. Alguém cujos ímpetos atuavam na denúncia de desigualdades e injustiças, ao mesmo tempo em que estava ligado a princípios e práticas políticas que atendiam a interesses dos trabalhadores. Esse viés efusivo de sua imagem pública era contrabalançado pela figura de um administrador racional e eficiente, simbolizada pela vassoura e por seus bilhetinhos, com os quais se incluía e era incluído num cânone de representação dos governantes nas democracias ocidentais, em sua figuração como burocrata. Em suas aparições públicas trajando slacks, enfim, procurou sintetizar seu programa de governo, seja com a manutenção do monopólio estatal do petróleo, a divulgação da PEI, o compromisso com a democracia cristã e a maior racionalização da burocracia estatal. Tais lances, em larga medida discutidos previamente com equipe de assessores, foram mostras de personalismo acompanhadas de propostas para transformar o cenário político com o qual se deparava. E receberam ampla divulgação da mídia por meio de retratos e ilustrações que parecem ter politizado significativamente as discussões públicas.

\section{REFERÊNCIAS}

ABREU,Alzira A. de et al.(Org.). Dicionário Histórico-Biográfico Brasileiro. Rio de Janeiro: Editora FGV, 2001.

AMÁDIO,José. Ninguém conhece ninguém. O Cruzeiro, Rio de Janeiro, 15 out. 1960, p. 14-15.

ARAÚJO, Braz J. de. A política externa no governo de Jânio Quadros. In:ALBUQUERQUE, José A. G. (Org.). Sessenta anos de política externa brasileira (1930-1990). São Paulo: Cultura, 2000.

BALANDIER, Georges. Le pouvoir sur scènes. Paris: Balland, 1992.

BARTHES, Roland. Mytbologies. Paris: Seuil, 1957.

BELOCH, Israel; FAGUNDES, Laura R. (Org.). Uma bistória escrita por vencedores: 50 anos do prêmio Esso de jornalismo. Rio de Janeiro: Memória Brasil, 2006.

BENEVIDES, Maria Victória M. O РTB e o trabalbismo: partido e sindicato em São Paulo (19451964). São Paulo: Brasiliense, 1987. 
BOTTO,Almirante Carlos P. A desastrada política exterior do presidente Jânio Quadros. Petrópolis:Vozes, 1961.

BURKE, Peter. Testemunha ocular: imagem e história.Trad.Vera Maria Xavier dos Santos. Bauru: Edusc, 2004.

CABRAL, Castilho. Tempos de Jânio e outros tempos. Rio de Janeiro: Civilização Brasileira, 1962.

CARDOSO, Miriam L. Ideologia do desenvolvimento. Brasil: JK e JQ. Rio de Janeiro: Paz e Terra, 1978.

CASTRO, Viriato de. O fenômeno Jânio Quadros. São Paulo: José Viriato de Castro, 1959.

CHAIA, Vera. A liderança política de Jânio Quadros (1947-1990). Ibitinga: Humanidades, 1991.

DINES,Alberto; FERNANDES JUNIOR, Florestan; SALOMÃO, Nelma (Org.). Histórias do poder. 100 anos de política no Brasil. São Paulo: Editora 34, 2000.

FERREIRA, Jorge. Plano CP: Revolução em São Paulo. O Cruzeiro, Rio de Janeiro, 1 de ago. 1959, p. 68-70.

(Org.). O populismo e sua bistória. Rio de Janeiro: Civilização Brasileira, 2001.

FRANCASTEL, Pierre. A realidade figurativa. Trad. Mary Amazonas Leite de Barros. São Paulo: Perspectiva, 1993.

GUEIROS, José Alberto. Depois da linha JQ, a linha BN. O Cruzeiro, Rio de Janeiro, 6 maio 1961, p. 30-33.

HAROCHE, Claudine. Da palavra ao gesto. Trad. Ana Montoia; Jacy Seixas. Campinas: Papirus, 1998.

MAGALHÃES, Felipe S. Varrendo Jânio: trajetória parlamentar (1947-1953). 1998. 202 f. Dissertação (Mestrado em História) - Faculdade de Ciências Sociais, Pontifícia Universidade Católica de São Paulo, São Paulo, 1998.

MAUAD,Ana Maria. Os tempos da narrativa: fontes orais e visuais na produção dos sentidos da história. In: SEMINÁRIO MEMÓRIA, CIÊNCIA E ARTE: RAZÃO E SENSIBILIDADE NA PRODUÇÃO DO CONHECIMENTO, 5.,19 out. 2007, Campinas. Trabalbo Apresentado. Campinas: Unicamp, 2007.

NASSER, David.Ao homem que entr. O Cruzeiro, Rio de Janeiro, p. 4-5,19 nov. 1960.

PEREIRA, J. Bilbetinhos de Jânio. São Paulo: Musa; Eliyahu Behar, 1959.

PRESTES, Luiz Carlos. Por que os comunistas apoiam Lott e Jango. [Rio de Janeiro]:Vitória, 1960.

QUELER, Jefferson J. Entre o mito e a propaganda política: Jânio Quadros e sua imagem pública (19591961). 2008. Tese (Doutorado em História) - Instituto de Filosofia e Ciências Humanas, Universidade Estadual de Campinas, Campinas, 2008.

SANTOS,Vidal dos; MONTEIRO, Luiz. Diário de uma campanha. São Paulo: Exposição do Livro, [196?].

SCHULTE, Rosa. [Carta de leitor]. O Cruzeiro, Rio de Janeiro, 15 out. 1960.p. 18. 
SILVA, Silvana L. Prata da casa: fotógrafos e fotografia no Rio de Janeiro (1950-1960). 2009. Tese (Doutorado em Comunicação) - Instituto de Artes e Comunicação Social, Universidade Federal Fluminense, Niterói, 2009.

SOUSA, Pompeu de. Bilhetinhos a Jânio. Brasília: Cegraf, 1987.

TAVARES, Flávio. O dia em que Getúlio matou Allende. Rio de Janeiro: Record, 2004.

VITA, Maurício; ESCOBAR, Mauro.Jânio e a volta ao mundo. São Paulo: Eliyahu Behar, 1959.

WALMSLEY, Silvana. M. de M. Origens do janismo. São Paulo (1948-1953). Dissertação (Mestrado em História) - Instituto de Filosofia e Ciências Humanas, Universidade Estadual de Campinas, Campinas, 1992.

WEFFORT, Francisco. O populismo na política brasileira. Rio de Janeiro: Paz e Terra, 1978.

YAMASHIRO, José.Jânio: vida e carreira política do presidente. Porto Alegre: Livraria Lima, 1961. 